\title{
High division of sciatic nerve associated with a double superior gemellus muscle
}

\author{
DUPIM, A. B. F. ${ }^{1}$, TEIXEIRA, A. R. ${ }^{2}$, PIRES, L. A. S. ${ }^{1}$ and \\ CHAGAS, C. A. A. ${ }^{1 *}$

\begin{abstract}
${ }^{1}$ Morphology Department, Biomedical Institute, Universidade Federal Fluminense - UFF, Rua Professor Ernani Mello, 101, São Domingos, CEP 24210-150, Niterói, RJ, Brazil

${ }^{2}$ Post-graduation Program, Biophysics Department, Health Sciences Center, Universidade Federal do Rio de Janeiro - UFRJ, Avenida Carlos Chagas Filho, Cidade Universitária, CEP 21941-590, Rio de Janeiro, RJ, Brazil
\end{abstract} \\ *E-mail:chagascaa@gmail.com
}

\begin{abstract}
Introduction: The superior gemellus muscle is a lateral rotator of the thigh, functioning together with other muscles of the region such as the piriformis muscle. The sciatic nerve is the largest nerve of the human body. It arises from the lumbosacral plexus and divides into two nerves: the tibial and common fibular nerves, which normally appear near the apex of the popliteal fossa. It is responsible for the innervation of the muscles of the posterior compartment of the lower limb. Case report: We report a doubled superior gemellus muscle associated with a high division of the sciatic nerve on the left side of a cadaveric specimen. The other muscles of the region showed no abnormality. Conclusion: This variation may offer information to piriformis muscle syndrome and be of importance in radiology and surgery of the region.
\end{abstract}

Keywords: anatomic variation, superior gemellus muscle, sciatic nerve, piriformis syndrome.

\section{Introduction}

The superior gemellus muscle (SGM) originates at the sciatic spine and the lower border of the greater sciatic notch, and inserts itself on a combined tendon with the obturator internus and the inferior gemellus muscle on the superior margin of the greater trochanter (TESTUT and LATARJET, 1954; FERNANDES, LAZZOLI, MANAIA et al., 2013).

The SGM is innervated by a branch of the sacral plexus or from the obturator internus nerve and its blood supply comes from branches of the internal pudendal artery. It is a lateral rotador of the thigh (TESTUT and LATARJET, 1954; FERNANDES, LAZZOLI, MANAIA et al., 2013).

The sciatic nerve $(\mathrm{SN})$ is the thickest nerve in the body. It arises from the lumbosacral plexus by the ventral roots of L4-S3, on the pelvis, and reaches the gluteal region through the greater sciatic foramen, below the piriformis muscle (PM) (TESTUT and LATARJET, 1954; PIRES, CHAGAS, FERNANDES et al., 2016).

It lies deep to gluteus maximus, crossing the obturator internus, the gemelli and quadrates femoris muscles posteriorly. Then, the nerve reaches the thigh and divides into its two components, common fibular and tibial, near the apex of the popliteal fossa. However, the point of division of the $\mathrm{SN}$ is very variable, and may occur at any level above this point (MUTHU, SRIMATHI, RANI et al., 2011; TOMASZEWSKI, GRAVES, HENRY et al., 2016; PIRES, CHAGAS, FERNANDES et al., 2016).

Variations of both SGM and SN possess a clinical interest, as they are necessary to understand the pathophysiology and correctly diagnose piriformis syndrome (PS), coccygodynia, sciatica, and muscle atrophy, since they can result in sensory and motor losses, causing flail foot and severe difficulty in walking
(BABINSKI, MACHADO and COSTA, 2003; BERIHU and DEBEB, 2015; PIRES, CHAGAS, FERNANDES et al., 2016).

Variations in the $\mathrm{SN}$ origin or trajectory can lead to iatrogenic injuries during total hip arthroplasty and intramuscular injections (PIRES, CHAGAS, FERNANDES et al., 2016). Furthermore, anesthetic blocks of the SN on the popliteal fossa have been recently performed in order to carry out orthopedic and plastic surgery interventions (REINOSO-BARBERO, SAAVEDRA, SEGURA-GRAU et al., 2014; PIRES, CHAGAS, FERNANDES et al., 2016).

This paper describes an anatomic variant where a high division of the SN has an interesting relationship with a doubled SGM.

\section{Case Report}

A male cadaver fixated with a $10 \%$ formalin solution was dissected during an anatomy class. It was found on his left gluteal region a high division of the $\mathrm{SN}$ and an accessory SGM. The SN passed through the greater sciatic foramen, beneath the inferior border of the PM and soon divided into $\mathrm{TN}$ and CFN. Both branches were located between the inferior border of the PM and the superior border of the accessory SGM (Figure 1).

No variations were identified on the right side, and the SN passed beneath piriformis and divided in the level approximate of the obturator internus and gemelli.

\section{Discussion}

During embryonic development, the $\mathrm{SN}$ is formed by the 5 lumbar and 5 sacral somites together with the whole lumbosacral plexus, bones and muscles of the region. On the 


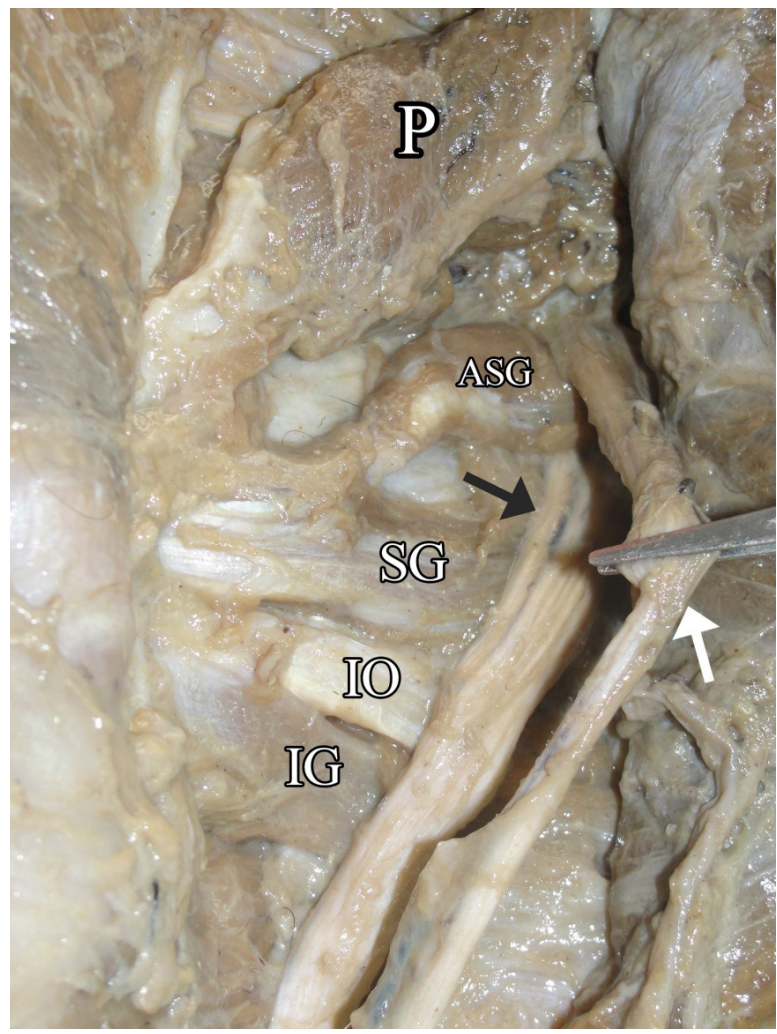

Figure 1. Posterior view of the gluteal region. Legend: $\mathrm{P}=$ Piriformis Muscle; ASG = Acessory Superior Gemellus Muscle; SG = Superior Gemellus Muscle; IO = Obturator internus muscle; IG = Inferior gemellus muscle. Black arrow: tibial nerve; White arrow: common fibular nerve.

fourth week, as the lower limb bud develops, motor fibers begin to appear and the ventral primary rami of the spinal cord originates, and are subdivided into a dorsal (CFN) and ventral (TN) components, to innervate their respective regions (SCHOENWOLF, BLEYL, BRAUER et al., 2014; MOORE, PERSAUD and TORCHIA, 2015).

On the other hand, the SGM is formed through the lower limb myotomes. During the fifth week of development, myogenic precursors start to migrate to the limbs, then, the myoblasts forms two large condensations (dorsal and ventral), which, through an apoptotic mechanism, starts to differentiate onto the individual muscles. On the lower limb, the ventral mass is responsible for the origin of some of the lateral rotators of the thigh, such as the obturator internus, gemelli, and quadratus femoris muscles, although the dorsal mass is responsible for the origin of the piriformis and gluteus muscles (SCHOENWOLF, BLEYL, BRAUER et al., 2014)

According to the literature, variations of the SGM are mainly its absence or duplication and it seems that the SGM is more prone to vary than the inferior. The SGM can also be fused with the piriformis or gluteus minimus muscles (FERNANDES, LAZZOLI, MANAIA et al., 2013; TUBBS, SHOJA and LOUKAS, 2016). Testut and Latarjet (1954) reports the absence of SGM in $8 \%$ of whites and $6 \%$ of blacks.

The $\mathrm{SN}$ is also subject to variation regarding its division into TN and CFN: it can divide in pelvis (4-20.9\%) (UGRENOVIĆ, JOVANOVIĆ, KRSTIĆ et al., 2005; POKORNÝ, JAHODA, VEIGL et al., 2006; ADIBATTI and SANGEETHA, 2014;
TOMASZEWSKI, GRAVES, HENRY et al., 2016), in the gluteal region $(8 \%)$ (MUTHU, SRIMATHI, RANI et al., 2011), the posterior upper thigh (14\%) (MUTHU, SRIMATHI, RANI et al., 2011), posterior middle thigh (38\%) (MUTHU, SRIMATHI, RANI et al., 2011), posterior lower thigh (12\%) (MUTHU, SRIMATHI, RANI et al., 2011) or the popliteal fossa (32\% and 46\%) (MUTHU, SRIMATHI, RANI et al., 2011; ADIBATTI and SANGEETHA, 2014).

Entrapment of the $\mathrm{SN}$ by the PM is a condition known as PS, a clinical entity which causes pain on the buttock and leg, and accounts for 6 to $8 \%$ of low back pain cases (VAS, PAI, PAWAR et al., 2016; PIRES, CHAGAS, FERNANDES et al., 2016). The PS is a controversial clinical entity due to the lack of strict diagnostic criteria and its accuracy regarding the actual pressure caused by the PM, as, supernumerary muscles, muscle hypertrophy of the lateral rotators of the thigh, and different trajectories of the $\mathrm{SN}$ can be the predisposing factor (PIRES, CHAGAS, FERNANDES et al., 2016). Furthermore, PS doesn't have a standard method in diagnosis nor treatment, although most of the literature states that dissection or decompression of the PM and SN are the most usual choices of surgical treatment (KOSUKEGAWA, YOSHIMOTO, ISOGAI et al., 2006; MOON, NAM, KWON et al., 2015). Drugs such as non-steroidal anti-inflammatory drugs, muscle relaxants, pregabalin, gabapentin can be used. Local injection of lidocaine, triamcinolone, and even botulinum toxin has been proving to be useful in a great number of patients (MILLER, WHITE and ROSS, 2012).

Diagnosis of this syndrome is usually performed with a computed tomography, magnetic resonance imaging, perineurography of the SN. Patients may present Pain's sign (pain and weakness with resisted hip external rotation and abduction) and Freiberg's sign (pain with passive internal rotation of the hip), although both signs are unspecific and are present in roughly $65 \%$ of patients, also, the Beatty test (reproduction of buttock pain with abduction of the thigh against gravity with patient in lateral decubitus position) can be performed (KOSUKEGAWA, YOSHIMOTO, ISOGAI et al., 2006).

Differential diagnosis should include other compressions forms of the $\mathrm{SN}$, such as from an intervertebral disc due to herniation or other diseases, like hematoma and pelvic tumour, radiculopathy, focal entrapment neuropathy, and sciatic nerve palsy (MILLER, WHITE and ROSS, 2012).

Vas, Pai, Pawar et al. (2016) also proposes that the gemelli and obturator internus muscles can also participate in this syndrome, due to the fact that they are in the same myofascial compartment and possess a strong relation with the $\mathrm{SN}$, the author emphasizes the gemelli muscles, which, together with the PM, could cause a "scissor like" effect on the SN, thus, leading to compression.

Anesthetic blocks on the popliteal fossa are performed in pediatric patients, during orthopedics and plastic surgery procedures with the objective of blocking both branches of the $\mathrm{SN}$, although, this can be easily addressed with the aid of an ultrasound during the anesthetic block procedure (REINOSO-BARBERO, SAAVEDRA, SEGURA-GRAU et al., 2014; BERIHU and DEBEB, 2015). Regarding the high division of the SN, it can greatly interfere in anesthetic blocks of the thigh, as it seems its point of bifurcation can often vary (MUTHU, SRIMATHI, RANI et al., 2011; ADIBATTI and SANGEETHA, 2014; TOMASZEWSKI, GRAVES, HENRY et al., 2016; PIRES, CHAGAS, FERNANDES et al., 2016). 


\section{Conclusion}

In conclusion, the SGM is prone to vary, although its variation rate regarding its duplication has not been addressed. We add further data regarding the implications of the SGM role during PS, as it seems it is not only caused by the PM, and the other muscles of the compartment can contribute to this disease. The $\mathrm{SN}$ has a variable point of division, and this may lead to an incorrect anesthetic block of this nerve.

\section{References}

ADIBATTI, M. and SANGEETHA, V. Study on variant anatomy of sciatic nerve. Journal of Clinical and Diagnostic Research, 2014, vol. 8, n. 8, p. AC07-AC09. PMid:25302181.

BABINSKI, MA., MACHADO, FA. and COSTA, WS. A rare variation in the high division of the sciatic nerve surrounding the superior gemellus muscle. European Journal of Morphology, 2003, vol. 41, n. 1, p. 41-42. PMid:15121548. http://dx.doi.org/10.1076/ ejom.41.1.41.28099.

BERIHU, BA. and DEBEB, YG. Anatomical variation in bifurcation and trifurcations of sciatic nerve and its clinical implications: in selected university in Ethiopia. BMC Research Notes, 2015, vol. 8, n. 1, p. 633 PMid:26526618. http://dx.doi.org/10.1186/s13104-015-1626-6.

FERNANDES, RMP., LAZZOLI, JK., MANAIA, JHM. and BABINSKI, MA. Bilateral absence of superior gemellus muscle in elderly cadaver. International Journal of Morphology, 2013, vol. 31, n. 3, p. 902-904. http://dx.doi.org/10.4067/S0717-95022013000300020.

KOSUKEGAWA, I., YOSHIMOTO, M., ISOGAI, S., NONAKA, S. and YAMASHITA, T. Piriformis syndrome resulting from a rare anatomic variation. Spine, 2006, vol. 31, n. 18, p. E664-E666. PMid:16915082. http://dx.doi.org/10.1097/01.brs.0000231877.34800.71.

MILLER, TA., WHITE, KP. and ROSS, DC. The diagnosis and management of piriformis syndrome: myths and facts. The Canadian Journal of Neurological Sciences, 2012, vol. 39, n. 5, p. 577-583. PMid:22931697. http://dx.doi.org/10.1017/S0317167100015298.

MOON, HB., NAM, KY., KWON, BS., PARK, JW., RYU, GH., LEE, HJ. and KIM, CJ. Weakness caused by bilateral piriformis syndrome: a case report. Annals of Rehabilitation Medicine, 2015, vol. 39, n. 6, p. 1042-1046. PMid:26798622. http://dx.doi.org/10.5535/ arm.2015.39.6.1042.

MOORE, K., PERSAUD, T. and TORCHIA, M. The developing human: clinically oriented embryology. 10th ed. Philadelphia: Saunders, 2015.
MUTHU, KT. SRIMATHI, RANI, A. and LATHA, S. A cadaveric study of sciatic nerve and it's level of bifurcation. Journal of Clinical and Diagnostic Research, 2011, vol. 5, n. 8, p. 1502-1504.

PIRES, LAS., CHAGAS, CAA., FERNANDES, RMP., SILVA, CRCM., CAVALCANTE, MA. and BABINSKI, MA. Anatomical variation of sciatic nerve: a case report of high division and unusual anastomosis with the posterior femoral cutaneous nerve. European Journal of Anatomy, 2016, vol. 20, n. 4, p. 365-369.

POKORNÝ, D., JAHODA, D., VEIGL, D., PINSKEROVÁ, V. and SOSNA, A. Topographic variations of the relationship of the sciatic nerve and the piriformis muscle and its relevance to palsy after total hip arthroplasty. Surgical and Radiologic Anatomy, 2006, vol. 28, n. 1, p. 88-91. PMid:16311716. http://dx.doi.org/10.1007/ s00276-005-0056-x.

REINOSO-BARBERO, F., SAAVEDRA, B., SEGURA-GRAU, E. and LLAMAS, A. Anatomical comparison of sciatic nerves between adults and newborns: clinical implications for ultrasound guided block. Journal of Anatomy, 2014, vol. 224, n. 2, p. 108-112. PMid:24433381. http://dx.doi.org/10.1111/joa.12128.

SCHOENWOLF, G., BLEYL, S., BRAUER, P. and FRANCIS-WEST, P. Larsen'shuman embryology. Philadelphia: Churchill Livingstone, 2014.

TESTUT, L. and LATARJET, A. Tratato de anatomía humana. Barcelona: Salvat, 1954.

TOMASZEWSKI, K., GRAVES, M., HENRY, B., POPIELUSZKO, P., ROY, J., PEKALA, P., HSIEH, W., VIKSE, J. and WALOCHA, J. Surgical anatomy of the sciatic nerve: a meta-analysis. Journal of Orthopaedic Research, 2016, vol. 34, n. 10, p. 1820-1827. PMid:26856540. http://dx.doi.org/10.1002/jor.23186.

TUBBS, R., SHOJA, M. and LOUKAS, M. (Eds.). Bergman's comprehensive Encyclopedia of human anatomic variation. Hoboken: Wiley-Blackwelled, 2016.

UGRENOVIĆ, S., JOVANOVIĆ, I., KRSTIĆ, V., STOJANOVIĆ, V., VASOVIĆ, L., ANTIĆ, S. and PAVLOVIĆ, S. The level of the sciatic nerve division and its relations to the piriform muscle. Vojnosanitetski Pregled. Military-Medical and Pharmacentical Review, 2005, vol. 62, n. 1, p. 45-49. PMid:15715349. http://dx.doi.org/10.2298/ VSP0501045U.

VAS, L., PAI, R., PAWAR, KS. and PATTNAIK, M. "Piriformis syndrome": is it only piriformis? Pain Medicine, 2016, vol. 17, n. 9, p. 1775-1779. PMid:26995801. http://dx.doi.org/10.1093/ $\mathrm{pm} / \mathrm{pnw} 037$. 